\title{
Use of Manipulative Media as A Stimulation of Ability To Understand The Concept of Early Children's Age
}

\author{
Agustina Nur Palupi ${ }^{1}$ \\ ${ }^{1}$ Early Childhood Education, Muhammadiyah Surakarta University
}

\begin{abstract}
Every child has the right and needs for stimulation of his development. One of them is cognitive. Aspects of cognitive development can be stimulated through mathematics learning. But children can find it difficult to understand mathematical concepts because reasoning and logic are needed, whereas mathematical concepts are not concrete. For this reason, concrete media need to be used to demonstrate or illustrate the concept, the media are manipulative. The purpose of this study is to analyze articles and documents resulting from research on the use of manipulative media as a stimulation of the ability to recognize the concept of child numbers.

Method: This research uses a literature review method. There are criteria in searching journals so that 20 journals are found to be analyzed based on population, sample, variables, data analysis, type of research design, and research results. Results and discussion: Literature review shows that the use of manipulative media in early childhood education varies greatly in terms of media material, its play, and its effectiveness. The manipulative media in question such as grain media, number blocks, clock puzzles, container marbles, picture cards, congklak numbers cards, numbers fishing games, and others. While the ability to recognize the concept of numbers in question such as the meaning of the symbol number of concepts a lot a little, counting, and others. Statistical analysis shows the application of manipulative media can stimulate the ability to recognize the concept of numbers in children, increase the activities of children and teachers, and found the response of children who are happy with the use of manipulative media. Conclusion: Manipulative media can stimulate the ability to recognize the concept of child numbers.
\end{abstract}

\section{KEY WORDS}

Mathematics learning, manipulative media, number concepts

\section{CORRESPONDING AUTHOR:}

email: agustinanurpalupi@gmail.com

Manuscript submitted October 10, 2020; accepted December 27, 2020.

Copyright: (2020 This is an open access article under the terms of the Creative Commons Attribution License, which permits unrestricted use, distribution, and reproduction in any medium, provided the original author and source are credited.
ECRJ (Early Chilhood Research Journal)

ISSN Numbers: Print, 2655-6448; Online, 2655-9315

\section{ADDRESS}

Website: http://journals.ums.ac.id/index.php/ecrj

Address: Pendidikan Guru PAUD

Universitas Muhammadiyah Surakarta

A. Yani Street No. 1, Pabelan, Kartasura, Surakarta, Indonesia

Telp. +62-271-717417 ext.

Email: ecrj@ums.ac.id

\section{INTRODUCTION}

Educating early childhood means guiding, caring for, and providing learning activities that will produce the abilities and skills of children. All of these efforts aim to build a child's self- foundation for growth and development which includes cognitive, social emotions, creativity, physical strength, and spiritual strength of children (Pradana, 2016: 19). Early childhood is the most important time for individuals, where 
the age of 4-6 years is a golden age because most of the capacity of individual abilities are formed at this age and will be carried to adulthood. Therefore efforts to educate and stimulate child development are needed. For a better child's life in the future. (Riyati \& Hasibuan, 2018: 2)

One important aspect of growth and development is cognitive. Cognitive ability is how children can find out, think, and explore. Cognitive abilities provide important impacts such as knowledge, ability to overcome problems, to the character that makes them able to understand the world around them. There are three important things in developing a child's cognitive abilities, namely the ability to think logically, think symbolically, and be able to solve problems. Thus, one of the right learning in stimulating children's cognitive is mathematics. In learning mathematics, children will think logically through counting and matching, think symbolically through recognizing the symbol of numbers, and in the end, the knowledge gained will be able to be used in daily life such as when buying goods, counting toys, and distributing food, and others. (Syafitri, 2018: 194)

In learning mathematics, an indicator of success is needed as a reference as well as the goal of achievement. As in Government Regulation No. 58 of 2009 concerning the ability to recognize numbers symbols, can say many objects 1-10, understand the concept of many little, know the symbol of numbers, recognize the concept of numbers. Thus introducing the concept of numbers is a basic stage that is needed in teaching mathematics to children. The concept of numbers is a set of objects or numbers that gives an understanding or meaning. By knowing the meaning, concept, and understanding of child symbols and numbers, they will be able to do more, namely to operationalize numbers. (Astuti, 2017: 3)

In 2015 the Program for International Assessment (PISA) conducted a performance evaluation test for Indonesian students in terms of science, mathematics, and reading. Where is the result that Indonesian students get low average scores and rank in a range of 69 countries (Eve and Putra, 2018: 2). It is undeniable that mathematics becomes difficult and even fear for some students. Where this causes poor performance. For this reason, getting used to mathematics from an early age is very much needed.

However, early childhood education also still has various obstacles. The lack of media is a constraint that can hinder the development of learning. Like the frequent use of student worksheets that are excessive or monotonous. The method applied is also still very classical and lack of innovation. This can hamper children's enthusiasm and interest in learning especially when learning mathematics. While the enthusiasm and interest of children are very important in the process of receiving material in children. The result is that it is still common to find children who are still wrong in counting, not yet able to use fingers to count, until they are not yet able to group objects according to their numbers. Children need a longer thought process in understanding the concept of numbers.

According to Anggorowati (Rosmalina, 2018: 2) mathematical concepts that are not 
concrete, need reasoning and logic can make it difficult for children to grasp the intent of the concept. This difficulty is feared to make children depressed and have no interest in mathematics. Therefore we need a media that can present, demonstrate, and illustrate mathematical concepts, so that meaning can be digested and captured by children more easily. Thus using manipulative media is one solution. Muhsetyo (Rizki, 2017: 48) states that manipulative media are media that can be reversed, cut, moved, moved, drawn, added, selected, grouped or classified to explain mathematical concepts and procedures. According to Yeni (Rosmalina, 2018: 3). media or manipulative objects are learning devices in the form of physical objects that can be manipulated, modeled, and demonstrated mathematical concepts and processes. Manipulative media can be used in early childhood were at that age children are entering a preoperational stage of development in which children begin to present their surrounding environment, as well as when they form stable and reasoned concepts.

Manipulative media can be in the form of cardboard, cloth, plastic, pencils, food, cutlery, cans, bottles, ropes, bottle caps, rubber, twigs, leaves, rocks, flowers, seeds, and others (Seefeldt and Wasik, 2008: 129). To then these objects are used as a visual aid of the concept of numbers, for example, numbers with the symbol number " 3 " with the name "three" modeled by 3 pieces of bottle caps that present the meaning or understanding of numbers or numbers 3 . The use of this manipulative media can be created into play activities so that children feel happy and comfortable. The use of manipulative media for children can also provide other benefits, where manipulating children's learning media can be stimulated in thinking and reacting with their environment. Allow children to work with multi-purpose materials, provide more opportunities to explore their curiosity and ignorance, and find the answers. These experiences help children think about their world in their way of understanding that there are many ways to solve problems, produce and provide many solutions to children's problems is a strategy for stimulating their thinking abilities. This can arouse the enthusiasm and motivation of children towards difficult math learning, by using manipulative media that is packed with games that will instill children's understanding that learning mathematics is easy and fun. In using this flexible manipulative media, the teacher will also practice providing media that is following existing principles. As chosen media has been agreed. It is also better if the media used is safe. The selected media should also be used by many people, multipurpose, and easy to use also sought (Latif, 2016: 155156). With creativity teachers, learning can develop, create fresh experiences, and provide satisfaction for children.

Mathematics is one of the important learning activities for children because it is centered on cognitive and knowledge can be used in children's daily lives. but in learning mathematics, some children often have difficulty understanding. As well as the lack of innovation and creativity of teachers in delivering the material becomes its constraints. Seeing the urgency of 
manipulative media in learning mathematics in being a solution to children's problems and the lack of innovation, the writer is interested in discussing "the use of manipulative media as a stimulation of the ability to recognize the concept of early childhood numbers"

\section{RESEARCH METHOD}

This type of research is the literature review. In the research literature review researchers collect data through libraries that can be encyclopedias, newspapers, scientific journals, magazines, or books, and other documents (Sukmadinata, 2009: 52). Researchers analyzed the use of manipulative media as stimulation of the ability to recognize the concept of early childhood numbers. There are dependent and independent variables that are the focus. For the independent variable that is the use of manipulative media and the dependent variable here is the ability to recognize the concept of numbers.

The population here are all research articles with the topic of using manipulative media as stimulation of the ability to recognize the concept of early childhood numbers. Samples of all research articles with the topic of the use of manipulative media as stimulation of the ability to recognize the concept of early childhood numbers. There are criteria in this research, namely: 1) Experimental or class action research, 2) Independent variables of research related to manipulative media, 3) The dependent variable of research relates to the ability to recognize the concept of numbers, 4) Respondents in this study are children with an age range of 2-10 years, 5) Research conducted is located in early childhood education and elementary school, 6) National articles with the last 5 years and international articles with the last 7 years. Selection of articles, of course, by considering the quality, quality, and reputation. The flow of reviewing the articles in the literature review is carried out following Figure 1.

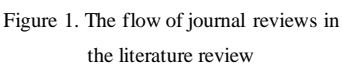

100 research journals found nationally and internationally

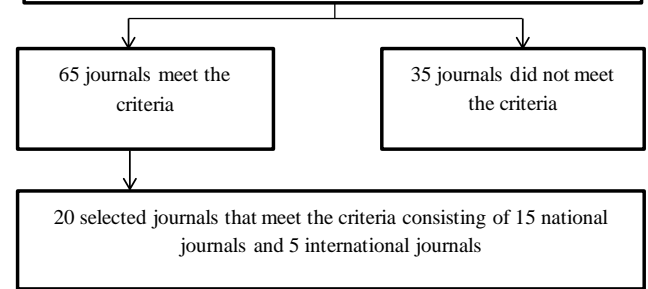

\section{RESULTS AND DISCUSSION}

The articles used as a reference there are 15 national articles and 5 international articles. Articles used as references contain research on the use of manipulative media such as clock puzzles, marbles, train numbers, ice cream sticks, counting trees, picture cards, dice, congklak, and number blocks. To express how effective and whether there is an influence on the ability to recognize the concepts of numbers in children such as counting, recognize symbols and numbers $1-10$, and the concepts of numbers are few. The research subjects in this referenced article range from 10 to 100 children with an age range of 4 to 10 years. The choice of the age range of research subjects 4 to 10 aims to further add insight into the results of whether manipulative media can still be effectively used by children after graduating from preschool. 
In the article used as a reference is quantitative research, 7 articles use the classroom action research design and 11 articles using experiments, 1 correlation study, 1 longitudinal, and cross-sectional study. The analysis techniques used include descriptive and qualitative descriptive statistics, t-test, Anova test, Manova test, Wilcoxon test, Wilcoxon test, Kolmogorov Smirnov test, Freidman test, Cross-Sectional correlational analysis, and Longitudinal analysis, and factorial analysis of covariance. The description of article analysis can be seen in this section.

\section{Stimulating the Ability to Recognize Group B} Number Concepts through Manipulative Media (Ni Made Putri Masyuni, et al, 2017) Researchers chose two classes, then two randomly selected classes were tested for equality with a pre-test and t-test, normality test, and homogeneity were performed. This is to find out the equivalence of two classes to be used as an experimental and control group. After both were given treatment subjected to a post-test found the highest value of the experimental group was 88 and the lowest was 54 with an average of 72.23 . While the control group scored the lowest 50 and the highest 79 with an average of 61.36 . This shows that the ability to recognize the concept of numbers can be stimulated with manipulative media.

\section{Stimulating the Ability of Concept Concepts of} 4-5-Year-Olds Using Ice Cream Stick Media (Dessy Musdyarty, et al, 2020)

This study gave the treatment of the use of ice cream stick media as a stimulation of the ability of the number concept. In 2 cycles the researcher assessed the ability to recognize the concept of numbers, children's activities, and the teacher who was the focus of the analysis. The average value for teacher activity was obtained $75 \%$ and 91.67 for the second cycle. While the activity of children in cycle one is $51.17 \%$ and cycle two is $76.90 \%$. For the use of media, the value of the ability of children in the pre-cycle amounted to 33.88 then after the teacher gave an action the use of ice cream stick media increased in cycle one to 38.26 and 58.77 in cycle two. The use of manipulative media in the form of ice cream sticks can improve the ability to recognize the concept of numbers and activities in learning

\section{Stimulating the Ability of Concept Numbers for Children Aged 5-6 Years Using Clock Puzzle Media (Wiwi Novita, et al, 2018)}

In this study, there is only one group. The flow of this research is observation, pre-test, treatment 1-4, then post-test. At the initial observation and test stage in the BSB category were 0 children, the $\mathrm{BSH}$ category were 4 children, the MB category was 11 children, and the $B B$ category was 0 children. In the treatment process, there was enthusiasm in learning. After the treatment, there were no post-test results for children in the $\mathrm{BB}$ and $\mathrm{MB}$ categories, there were $8 \mathrm{BSHs}$ and $7 \mathrm{BSB}$ children. the ability to recognize the concept of numbers can be stimulated by manipulative media such as a puzzle clock.

Stimulating the Ability of Concept Concepts of 4-5 Years Old Children Using the Media of Picture Cards (Meirita Astuti, et al, 2017) 
This research was conducted through 3 stages of the meeting. Every meeting there are 2 cycles. Before the cycle for the BB and MM categories, there were 5 children. With an average value obtained 29.36. So the researchers tried to apply the game using picture card media.

After using pictorial card media, it was found that in all the meetings of cycle one, it was found that the value of 41.8 was included in the developing criteria. For the second cycle in all meetings found a value of 82.25 and this is included in the criteria either. This means an increase. The use of manipulative media in the form of picture cards effectively increases the ability to recognize the concept of numbers. Researchers also analyzed the activities of teachers and children. For the activities of the first cycle teachers in all meetings scored 46.8 . Then get 81.5 in the second cycle. While the activity of the first cycle of children in all meetings can be 48.1 . Then get 82.25 in the second cycle. Thus the use of manipulative media in the form of picture cards is also effective in increasing the effectiveness of teachers and children in learning.

\section{Stimulating the Ability of the Concept of Age} Numbers 4-5 Years Using the Computational Tree Game Media (Ockti Syafitri, et al, 2018)

There are 3 meetings for each cycle one and two. Previously researchers with class teachers had discussed the theme. A learning plan has also been prepared. Researchers have also prepared the media for use. There are indicators used that are children connecting objects with numbers, children can sort and count.
In the first meeting, from the scale of assessment, the value of children reached $40 \%$ for numerical activities, $40 \%$ for connecting activities, $40 \%$ for sorting activities. At the second meeting, the value of the child reached $80 \%$ for the counting activity, $50 \%$ for the linking activity, $40 \%$ for the sorting activity. At the third meeting, the children's score reached $90 \%$ for activity, $80 \%$ for connecting activities, $55 \%$ for sorting activities. In cycle, teacher activities such as direction, demonstration, and interaction tend to increase and fall into either category. But for cycle one at the reflection stage, teachers found that they did not give rewards, the teacher's voice was not loud enough, and too fast to give examples.

Cycle two was found to be increased. The first meeting the value of the scale used reached $100 \%$ for numerating activities, $85 \%$ for connecting and sorting activities. In the second meeting, they reached $100 \%$ in the counting activities, and $65 \%$ in the sorting and connecting activities. At the third meeting, it reached $100 \%$ for numerating activities, and $80 \%$ for sorting and connecting activities. Even though it has a downward trend, it is better than cycle one. For the second cycle after being planned and evaluated from the reflection of cycle I the teacher's activities in all aspects described above fall into either category. Including the awarding

\section{Stimulating Cognitive Ability Using Dice Media (Joni, 2016)}

Research is carried out during the learning process. In the opening activity, the teacher motivates and attracts the child's interest in the material to be given. The learning phase is 
focused on the research objectives. After that rest and cover. This study has 3 indicators, where all indicators are about numerating in sequence, in reverse, and randomly. After observing, there are still children who have not been able to complete the task independently. After the use of manipulative media in the form of dice by counting numbers coming out of some dice, the ability to improve was improved. In cycle, one found 7 children got fewer grades, 11 children with enough grades, and 3 children with good grades. The second cycle shows an increase in where the child gets more good grades. The use of manipulative media in the form of dice is effective in increasing children's numeracy skills.

\section{Stimulating the Ability of Concept Numbers} for Children 4-5 Years Old Using the Number Train Media (Nurmala Sari, et al, 2017)

In the initial stages of the study, the researcher gave a pre-test on the sample to be studied. Researchers only made the sample in one group without a comparison group. Then the children were observed for their abilities based on the indicators used. Indicators include the child's ability to count according to many objects, able to sort numbers, and children able to match objects with numbers.

After finding the final score on each indicator, 10 students were included in the BB category, 9 children were in the MB category, 1 child was in the $\mathrm{BSH}$ category, and no children were in the BSB category. After being given treatment (treatment) then post-test is done most of the students experience an increase. There are no children who qualify for $B B, M B$ criteria for 1 child, there are 13 children for BSH criteria, and there are 6 children who are included in the BSB criteria. This study shows that $50.7 \%$ of children's abilities can be influenced by the media. While the rest can be influenced by various other factors.

\section{Stimulating the Ability of the Concept of Numbers Using Media Marbles Containers} (Ayu Dia Purnamasari Subagio, et al, 2018)

There are four treatments between the pretest and the post-test. The treatment activities I and II are the same. At this stage, the children are explained how to play container marbles. The teacher gave an example of how to play, namely by the way children ran to pick up marbles and then put them in a container. For treatments III and IV the same as before. But this time the child is challenged to complete the game in 30 seconds.

Pre-test training was also carried out in the same way. Here children use child worksheets. children are asked to match the number of marbles to the number symbol, and add up the number of marbles. After the child is finished and assessed the results of the post-test are found to be greater by 175 , while the pre-test is only 129 . This research shows that by playing to enter marbles, counting while counting can stimulate the child's ability to recognize the concept of numbers.

\section{Stimulating the Ability of Many Little Concepts and Number Concepts Using Congklak Carded Numbers (Riyati and Rachma Hasibuan, 2018)}

In this study, researchers used two groups that were treated and not. Both will be compared after treatment and assessed by the pre-post 
test. Of course, in selecting groups, researchers have considered equality. The group that is subject to treatment is given the influence or treatment that is the game of congklak with a number card. While the control group was not given the treatment of the game of congklak with a number card but in the form of a learning process that is done every day by using a stick.

To recognize the concept of numbers, after analyzing the data a significant value of 0.020 , and this is smaller than 0.050 . So that learning the game of congklak with a number card has a significant positive effect on the group being treated. But in the control group with learning to use a stick, there is no effect on the results of the final observation. As for the ability to understand the concept a lot or a little, after the analysis found significant values of 0 and this is smaller than 0.050 . So learning with this numbered congklak media has a positive effect on the group given treatment. Whereas the control group with learning using sticks did not affect the final observation results. This research shows that the ability to understand the concept of numbers and many concepts can be stimulated with media marbles with a numbered card.

\section{Stimulating the Ability of the Child's Number} Symbol Using Number Beams (Post-Hadi Pradana, 2016)

In this study, the correlation researchers to determine the relationship and influence between the ability of children to recognize the symbol of numbers by using the number beam media. Previously children have been explained how to play. The teacher has prepared media in the form of rectangular blocks which are written symbols of one to ten. The blocks have also been perforated to be pierced or installed in the space provided while sorting. In this activity, the children compete to compile precisely and quickly. The setting of the playing environment for beams is varied, the child is free to play and the blocks used also vary in shape and color.

Researchers assess through the criteria that researchers set. These criteria are that children can arrange the blocks correctly. Score three if the child is able, score two if good enough, score one if he doesn't want to do. After the assessment, the researcher recapitulated all of the children's values. After analysis, it was found that there were a good relationship and influence on children's understanding of the number symbol by using the media beam sequence.

\section{Stimulating the Ability of the Concept of Children's Numbers Grain Media (Winarsih and Mas'udah, 2017)}

In this study, the researchers focused on the sample studied as a group that was subjected to the use of grain media without a comparison group. In this study, there were four meetings divided into two cycles. There is a planning, implementation, observation, and reflection phase. Previously, the researchers had prepared a plan for implementing daily learning plans and research instruments that would be used. Then the researchers carried out their research by giving use of the seed media.

After implementation, there was an increase in the abilities, activities of children and teachers. 
These three things are assessed on a scale of one to four, and are formulated to find the percentage and fall into the category of very good (80-100), good (56-79), sufficient (26-55) or less (0-25). For the ability of children from $58.82 \%$ to $82.35 \%$. For children's activities from $67.5 \%$ to $92.5 \%$. Whereas teacher activity from $70 \%$ to $87.5 \%$. This research shows that to improve learning activities and children's ability to recognize and understand the concept of numbers can be used grain media.

\section{Stimulating the Ability of the Child's Number} Symbol Using the Red Playdough Game (Rachmawati and Sri Setyowati, 2018)

There were five meetings for the pre-test, three treatments, and a post-test. And some groups are subject to treatment and those who will not be invited to do the activity of pointing, counting, and imitating the numbers one to ten to be assessed. After pre-testing in the treated group, 2 children scored 5, 10 children scored 6 and 7 , and 2 children scored 8 . For those who were not subject to treatment, 3 children received a score of 5 , there were 10 children. children get a score of 6 and 7, there are 2 children get a score of 8 and 9 . For the results of the post-test in the group that is subjected to treatment, 1 child is getting a score of 9 , there are 11 children get a score of 10 and 11, there are 3 children get a score of 12 . In the group who were not subjected to treatment, there were 2 children with a score of 6 , there were 9 children who scored 7 and 8 , and there were 3 children who scored 9 and 10 . This research shows that using playdough to learn mathematics can stimulate children's abilities and understanding.
Stimulating the Ability of the Concept of Children's Numbers Using Games with Number Fishing (Izzaturroh- maniyah, et al, 2019)

This research was conducted in learning activities in the second semester and conducted in 2 cycles. Each meeting lasts for 60 minutes. The steps of the game are as follows: fish are placed in a tub, then fishing for the numbers that are in the fish in the tub, and mention these numbers. Then choose a picture and stick to the stick board with the same number as the number that has been lured. Then the educator asks the children in one group to take turns, then the two children in the group are asked to compare their acquisition by giving an equal sign $(=)$, if the results obtained, are the same and not the same $(\neq)$ if the results obtained are not the same.

At the time of the pre-cycle, the results obtained by students in knowing the concept of numbers are still in the criteria of lacking, only 4 children who completed or reached an average percentage of $23.56 \%$. In cycle, through fishing games, the number of children's abilities has increased. 9 students complete and reach an average percentage of $52.59 \%$ good criteria. Because it has not yet reached the $75 \%$ completeness criteria, a second cycle was held and it has produced 15 children who have completed it. This study aimed at playing math activities with media to stimulate numbers to stimulate children's abilities.

Improving Mathematics Learning Outcomes of Class V Students of Primary Schools Using 
Manipulative Media (Putu Rosmalina, et al, 2018)

There are groups that are subject to treatment and not subject to treatment. To then be assessed pre and post-test. The time of the preliminary study was in 2017 from November to 2018 in April. For mathematics material, the focus is the division and multiplication of fractions. The choice of material is based on the class selection in the study, namely class 5 . The assessment was found in the pre-test for the group that was subjected to treatment 21 children were incomplete and 1 child complete, with an average score after the assessment found 46.14. This result is actually below the group that is not subject to treatment, which is only 20 children who are incomplete and 2 children are complete, with an average score of 48.41 . For the posttest, in the group that was subjected to the treatment of the number of children who completed 20 and 2 children completed, with an average score of 69.32. For the group that was not subjected to treatment, only 15 children were complete the remaining 7 children were incomplete, with an average score of 62.95. Besides, researchers also assessed how students 'opinions were through questionnaires and the average score of 66 was found. This means that students' opinions felt helped by the media used.

\section{Improving Mathematical Connection Ability}

of Primary School Students Using Manipulative Media With Model Inquiry (Ummu Zulfah, et al, 2018)

There are two cycles where each cycle there are two meetings. This research was conducted without using a control group. This study combines the Inquiry model with manipulative media, to measure the improvement of children's mathematical connection abilities. There are mathematical connection indicators used in this study. The indicators understand the relationship of mathematical topics, apply their mathematical knowledge, understand existing mathematical concepts and procedures. After the assessment, a value of 62.98 was found for the mathematical connection capability before entering the cycle. Got an average value of 72.37 in the first cycle and 81.46 in the second cycle. For learning activities, students got an average value of 54.16 and increased to 66.34 in the second cycle. Students were also asked to respond via a questionnaire, found an accumulation of 3,069 scores and an average score of 74.85. All of the assessment results are included in the good category. The average score of the ability of teachers to manage mathematics learning activities from an average value of 2.86 to 3.29 and this is also included in both categories. The use of manipulative media effectively increases the ability and skills of mathematical connections in students, as well as effectively increasing the teacher's skills in teaching.

The Impact of Use of Manipulatives on the Math Scores of Grade 2 Students (Robert Scott Liggett 2017)

This study discusses the effect of using mathematical manipulative media to improve student test scores and student attitudes towards mathematics. The study took place at northern Saskatchewan school during fall 2016 
for two weeks. The first week involves the administration of the pre-test and the second week of the post-test. In this study, two groups were subjected to treatment and not. The assessment tool was made by the researcher and two-second grade teachers whose classrooms were involved in this study.

After the assessment, pre-test, and post-test, the group that was subject to treatment had a higher score than the group that was not subjected to treatment. The post-test scores of students in the group subjected to treatment using manipulatives were 18 percentage points higher than the test scores of participants in the group who were not subjected to treatment. This research shows that using manipulative media can improve children's grades and achievements in learning mathematics.

The Effects of Physical Manipulatives on Children's Numerical Strategies (Andrew Manches dan Claire O'Malley, 2016)

This article discusses whether and how manipulatives can affect a child's strategy in solving problems related to mathematics. This research is divided into two studies conducted. In the first study, it was conducted to examine the effect of physical material or manipulative media on solving mathematical problems by children compared to not using material manipulative media. The second study focuses on the benefits or limitations of manipulative media in encouraging the resolution of mathematical problems by children. Both studies use the same task or method.

The study focused on the concept of understanding numbers that can be arranged and decomposed. For example, assignments are given such as where children are asked to identify as many ways as possible to decipher numbers. By presenting a problem using the context of the story and concrete materials such as "The man in the yellow hat takes out the contents of his bag, the man has 5 candies and puts some in one bag and the rest in his pocket, the question is how to keep the bag or bag filled with candy? Children can answer with answers as diverse as " 3 in a bag and 2 in a bag." During the process of love, the narrator stimulates and continues to oversee the child's response. The assignment of the task is done using manipulative media and also not using. The results of the study in the first study based on the assessment through repeated right or wrong responses, it was found that by using manipulative media children identified more solutions. The results of the study in the second study after using some manipulative media researchers found that different media have different benefits. For this research, it shows that physical manipulative media is more useful than images. The use of manipulative media effectively improves children's abilities in learning mathematics. but keep in mind also the materials used.

\section{Manipulative Use and Elementary School Students' Mathematics Learning (Lida J. Uribe-Flórez dan Jesse LM Wilkins, 2016)}

This study examines the relationship between the use of manipulative media and mathematics learning in elementary school children. Using cross-sectional correlational analysis and longitudinal analysis. Correlation analysis to determine the relationship between 
the influence of the use of manipulative media on children's mathematics learning achievement. while longitudinal analysis to determine the development of children's achievement for a fairly long time. The sample of this research was kindergarten students who were observed until they entered elementary school in the United States. In total, the data set contained seven waves, namely 2 time points during the kindergarten year, 2 time points during class one, and 1 time during each grade year three, five, and eight. For the current study, researchers used data from four waves to examine the longitudinal growth rate in students' mathematics achievement during their primary school years. The four waves represent the basic measures, the 1999 spring semester of 1999, the first follow-up, the first class of the summer semester of 2000, the second follow-up, the third semester of the spring class of 2002 and the third follow-up, the fifth semester of the spring class of 2004 Using item response theory (IRT) techniques, members of the Early Childhood Longitudinal Study ECLS adjust test scores to make comparisons between waves. The IRT math scores range between 1 and 153 and represent the mathematical knowledge each student has at a certain time during elementary school. And children's activities using manipulative media are rated using a Likert scale. Research has found that the use of manipulative media decreases with the increasing class of children, the use of manipulative media is most widely used in kindergartens. Correlation analysis found a significant relationship and influence on children's mathematics learning. The longitudinal analysis shows that the growth of children's mathematical learning increases significantly with the level of medium manipulative media usage.

Instructional Guidance and Realism of Manipulatives Influence Preschool Children's Mathematics Learning (Kira J. Carbonneau dan Scott C. Marley, 2017)

This research highlights other variables that might influence the benefits of using manipulative media. These variables are instructional and the level of manipulative reality. For this reason, the researcher divided four conditions, namely low instructional guidance with gentle manipulatives, low instructional guidance with realistic manipulatives, high instructional guidance with gentle manipulations, and high instructional guidance with realistic manipulatives. The material in this study is the concept of many and little, with a series of crocodile games eating more amount of food or can be described as " 3 dots> symbol number 2".

Previously, researchers collected data on parental consent to allow their children to participate in the study. Previously they were given a pretest about understanding their mathematics to be equal. Then participants are introduced to the learning game in this study and random participants in the same amount are assigned to all conditions. Finally, three results are assessed namely procedural knowledge, conceptual knowledge, and transfer. In the low guidance instruction, the researcher only hinted or said the directions verbally. Whereas in high guidance instruction, 
researchers act as instructors, guiding participants by offering support through.

The results revealed that students who received high-level guidance outperformed those who received low instructional guidance. But it can be low instructional data that can give more benefits if done in a consistent time. Besides, the use of manipulative media that is soft or not too realistic can enhance student learning, because manipulative media that are gentle can focus attention and stimulate children's knowledge to capture the purpose of the game and apply it to other situations. But for students who are subject to low-level guidance, the use of realistic manipulative media can provide more benefits. So this study suggests that the use of manipulative media in learning should be adjusted to the level of guidance and the quality of the media.

\section{The effect of manipulatives on} mathematics achievement across different learning styles (Zeynel Kablan, 2016)

This research highlights the time or duration of the learning and learning styles of children. Mapping learning styles in this study uses the theory of David Kolb. The researcher divides 3 learning conditions, namely by learning $100 \%$ abstract with teaching methods in lectures and training, for the other two conditions $70 \%$ abstract-30\% concrete and $50 \%$ abstract or concrete equivalent, with the method. Every sample or student placed in the learning environment is given a pretest and finally a posttest. To maintain the influence of teacher learning styles, researchers use the same teacher in carrying out 2 experiments

Experiment 1 to examine the effect and differences in outcomes between students' learning styles on their mathematics learning. Researchers have divided the sample based on learning styles, namely accommodators, divergers, convergers, and assimilators. In Experiment 1 all samples were included in all learning conditions. Experiment 1 results show that in abstract learning it takes longer for teachers and students to achieve understanding success. In a learning environment that implements instructionbased lectures and exercises throughout the lesson period, the learning styles of assimilators and convergers score much higher than those of accommodators and diverse. In the other two learning environments, from teaching time dedicated to manipulative use, there is no difference in the achievement of all learning styles.

In experiment 2 to examine the comparison of the influence of the learning environment and the comparison of the results of northern and southern learning styles on their mathematics learning. The northern learning style consists of accomodating and 
diverging learning styles while the southern learning style consists of converging and assimilating groups. The results showed no difference in mathematics scores between students in different treatment groups and there were no differences in math scores between students with different learning styles. However, the results also showed southern styles outperforming northern styles in $100 \%$ abstract learning environments. But the northern style in abstract-concrete learning $70-30 \%$ of the environment outperformed the northern style in $100 \%$ abstract learning.

Researchers also compared with other studies and found that teaching methods can affect. Using manipulatives in mathematical teaching settings benefits certain learning styles to some extent. Excessive manipulative use may not help students. It should be understood that classroom learning should not only use one learning style because for students who are not suitable they need time to adapt. Then learning should be made more flexible for all students.

\section{Implications in Mathematics Learning Practices}

Based on the results of the analysis of 20 articles found one way to stimulate the ability to know the concept of numbers is to use manipulative media by using various media such as puzzle hours, marbles, train numbers, ice cream sticks, counting trees, picture cards, dice, congklak, and number blocks. Although the results of existing studies vary in their overall effect the research shows a positive effect. Teachers and parents as instructors can optimize the use of manipulative media through the method and selection of appropriate objects. as creative and compatible as possible with the situation.

Based on the analysis of 20 research journals, we recommend using manipulative media to be applied by both teachers and parents in learning mathematics in children. The use of manipulative media has several advantages, including 1 ) the cost required is cheap and can even be done without incurring costs; 2) media and games can be made as free and creative as possible because of the use of flexible and diverse materials; 3 ) can attract the attention and enthusiasm of children's learning; 4) can be accepted by children with an early age range until entering elementary school

However, it should also be noted that excessive use of manipulative media has the potential to reduce its effectiveness and that 
learning activities can be disrupted. Because it can arise boredom or confused because of the material and context of the game that is always changing. The teacher should pay attention to the choice of material that matches the material, to maximize the benefits. Teachers should also pay attention to learning styles and methods of instruction so they can adapt well and play manipulative media. The use of manipulative media must also be followed by understanding or knowledge to maximize potential.

\section{CONCLUSION}

The need for early childhood stimulation for its development is a task for parents and teachers as educators, to provide guidance, care, stimulate, and teach to hone the child's abilities and development. There is an important aspect in children, namely cognitive development, which includes children's thinking ability to solve various problems in the child's daily life. Where aspects of cognitive development can be stimulated through mathematical learning, and as a basis, it needs to be introduced to the concept of symbol numbers. The difficulty of learning mathematics plus the lack of media makes it difficult for children to learn. In the end, it will disrupt the ability and achievement of children. Then needed manipulative media help.

In general, the use of manipulative media has a good effect. Its use can increase teacher activities and can increase children's activities through a variety of materials that can be played. Children become happy and feel facilitated in learning mathematics because the information becomes easily captured.

Thus the use of manipulative media should be applied. Packaged in creativity and use of a variety of materials. And pay attention to the delivery method used and its duration. Also, consider the characteristics or preferences of children so that the use of manipulative media can be adjusted. The use of appropriate and good manipulative media can develop abilities and increase children's achievement, especially in mathematics.

\section{REFERENCES}

Astuti, Meirita. (2017). Meningkatkan Kemampuan Mengenal Konsep Bilangan Melalui Permainan Kartu Bergambar Pada Anak Usia 4-5 Tahun Di Paud Permata Hati Koto Baru Kuantan Singingi. Jurnal Online Mahasiswa Fakultas Keguruan dan IImu Pendidikan Universitas Riau, 4(1), 1-15

Hawa, Anni Malihatul dan Lisa Virdinarti putra (2018). PISA untuk siswa indonesia. Janacitta, 1(01), 1-8

Izzaturrohmaniyah, dkk. (2019). Penerapan Permainan Memancing Angka Untuk Meningkatkan Kemampuan Mengenal Konsep Bilangan Pada Anak Kelompok A Raudhatul Athfal Al Amin Bonangan Pakis Malang. Dewantara, 1(2), 57-64

Joni. (2016). Peningkatan Kemampuan Kognitif Anak dalam Kegiatan Berhitung dengan Permainan Dadu TK Mutiara Pekanbaru. Jurnal Obsesi : Jurnal Pendidikan Anak Usia Dini, 2(1), 1-10

Masyuni, Ni Made Putri. dkk. (2017). Pengaruh Metode Bermain Berbantuan 
Mediamanipulatif Terhadap Kemampuan Mengenal Konsep Bilangan Pada Anak Kelompok B. E-Journal Pendidikan Anak Usia Dini, 5(1), 65-7

Musdyarty, Dessy. dkk. (2017). Meningkatkan Kemampuan Konsep Bilangan Melalui Media Stik Es Krim Pada Anak Usia 4 - 5 Tahun Di Paud Epta Pandau Jaya Kecamatan Siak Hulu. Jurnal Online Mahasiswa Fakultas Keguruan dan IImu Pendidikan, 4(1), 1-12

Novita, Wiwi. dkk. (2018). Pengaruh Penggunaan Puzzle Jam Terhadap Kemampuan Mengenal Konsep Bilangan Pada Anak Usia 5-6 Tahun Di Paud Terpadu Harapan Negeri Kecamatan Bungaraya Kabupaten Siak. Jurnal Online Mahasiswa Fakultas Keguruan dan IImu Pendidikan Universitas Riau, 5, 1-15

Pradana, Pascalian Hadi. (2016). Pengaruh Permainan Balok Angka Terhadap Kemampuan Mengenal Lambang Bilangan Pada Anak Usia Dini. Jurnal PAUD Tambusai, 2(2), 18-25

Riyati \& Rachma Hasibuan. (2018). Pengaruh Permainan Congklak Berkartu Bilangan terhadap Kemampuan Mengenal Konsep Bilangan dan Konsep Banyak dan Sedikit pada Anak Usia Taman Kanak-Kanak. Early Childhood Education Journal of Indonesia, 1(1), 1-9

Rizki, Lidya Dita. dkk. (2017). Perbandingan Hasil Belajar Antara Pembelajaran Dengan Menggunakan Media Manipulatif Dengan Pembelajaran Konvensional. Jurnal Penelitian Pembelajaran Matematika Sekolah, 1(1), 47-53

Rosmalina, Putu. dkk. (2018). Pengaruh Penggunaan Media Manipulatif terhadap Hasil Belajar Matematika Siswa Kelas V SD. Jurnal Pedagogi, 7(9), 1-12
Sari, Nurmala. dkk. (2017). Pengaruh Permainan Kereta Angka Terhadap Kemampuan Mengenal Konsep Bilangan Pada Anak Usia 4-5 Tahun Di Paud Lestari Kecamatan Kemuning Kabupaten Indragiri Hilir. Jurnal Online Mahasiswa Fakultas Keguruan dan Ilmu Pendidikan Universitas Riau, 4(1), 2-12

Seefeldt, Carol \& Wasik, Barbara A. (2008). Pendidikan Anak Usia Dini. (pp. 129). PT Indeks. Jakarta.

Subagio, Ayu Dia Purnamasari dan Rachma Hasibuan. (2018). Pengaruh Media Kelereng Wadah Terhadap Kemampuan Mengenal Konsep Bilangan 10-20 Di Tk Karya Bhakti Kecamatan Tandes Kota Surabaya. PAUD Teratai, 7(2), 1-5

Sukmadinata, Nana Syaodih. (2009). Metode Penelitian Pendidikan. (pp. 52). PT. Remaja Rosdakarya : Bandung.

Syafitri, Ockti. dkk. (2018). Peningkatan Kemampuan Mengenal Konsep Lambang Bilangan 1 - 10 Melalui Permainan Pohon Hitung pada Anak Usia 4 - 5 Tahun di BKB PAUD Harapan Bangsa. Jurnal Al-Azhar Indonesia Seri Humaniora, 4(3), 193-205.

Utami, Rachmawati Putri dan Sri Setyowati. (2018). Pengaruh Bermain Playdough Merah Terhadap Kemampuan Mengenal Lambang Bilangan Pada Anak Kelompok A Tk Aratisari Surabaya. PAUD Teratai, 7(3), $1-7$

Winarsih dan Mas'udah. (2018). Meningkatkan Kemampuan Mengenal Konsep Bilangan 1-10 Melalui Media Biji-bijian Pada Kelompok A Di Tk Darul Hikmah 2 Karangan Bareng Jombang. PAUD Teratai, 7(1), 1-6

Zulfah, Ummu, dkk. (2018). Penerapan Model Inquiry Berbantuan Media Manipulatif Untuk Meningkatkan Kemampuan Koneksi 
Matematika Siswa Sd. ANARGYA: Jurnal Ilmiah Pendidikan Matematika, 1(1), 42-50

Liggett, Robert Scott. (2017). The Impact of Use of Manipulatives on the Math Scores of Grade 2 Students. Brock Education: A Journal of Educational Research, 26(2), 87101

Manches, Andrew dan Claire O'Malley. (2016). The Effects of Physical Manipulatives on Children's Numerical Strategies. Cognition and Instruction, 34, 27-50

Uribe-Flórez, Lida J. dan Jesse L. M. Wilkins. (2017). Manipulative Use and Elementary School Students' Mathematics Learning. International Journal of Science and Mathematics Education, 15, 1541-1557

Carbonneau, Kira J. dan Scott C. Marley. (2015). Instructional Guidance and Realism of Manipulatives Influence Preschool Children's Mathematichs Learning. The Journal of Experimental Education, 83, 495-513

Kablan, Zeynel. (2014). The effect of manipulatives on mathematics achievement across different learning styles. Educational Psychology : An International Journal of Experimental Educational Psychology, 36, 277-296 